\title{
救急車搬送数による 症候群サーベイランスのための基礎的研究
}

\author{
大日 康史 ${ }^{1}$ 川口 行彦 ${ }^{2}$ 菅原 民枝 ${ }^{1}$ 奥村 徹 ${ }^{3}$ \\ 谷口 $\quad$ 清州 $^{1} \quad$ 岡部 $\quad$ 信彦 1
}

\begin{abstract}
要旨 目的：バイオテロを含む異常な流行を早期探知するための症候群サーベイランスの候補の 一つとして救急車搬送数に着目し，その統計学的な性質を明らかにする。材料と方法：東京消防 庁が保有する 1995 年 1 月 1 日から 2004 年 12 月 31 日までの救急車搬送数のデー夕の内，主訴が 発熱であった救急車搬送数を対象とする。異常な救急車搬送数の増加の探知は，前半の 5 年間を ベースライン推定のためだけに用い，後半の 5 年間を前方視的に解析する。異常な救急車搬送数 の増加の探知は，実際の救急車搬送数がベースラインよりも残差の標準偏差の 3 倍以上を上回っ た場合と定義する。感度・特異度は，前方視的に分析された 5 年間で，異常な救急車搬送数の増 加が探知されていない日を対象に人為的に救急車搬送数を増加させ，それが探知されたかどうか で判断する。結果：ある行政区域に限定すれば平均的には $1.1 \% ， つ ま り$ 年 4 回程度で流行が探知 されたが，東京都全体では $39.7 \%$ ，つまり 2.5 日に一回異常な救急車搬送数の増加が探知された。 特異度は都全体，あるいは 23 区では非常に高く，追加的な救急車搬送数が 1 名であれば $90 \%$ を 越えている。感度も高く都全体では異常な救急車搬送数の増加の規模が 5 人であっても $73 \%$ の確 率で探知できる。考察：以上の成績からこのシステムの異常な救急車搬送数の増加を探知する能 力は優れていると判断される。したがって，その正確性を増し，また感度を落とさず特異度を上 げるためには他の側面をモニターしている症候群サーベイランスとの比較が必要不可欠であると 考えられる。救急車搬送の情報は既に電子的に記録されるシステムが確立しており，それを本稿 のような形で解析評価すれば，世界最大の人口を対象とする症候群サーベイランスとなる。その 実用性も極めて高いので，早急に東京都のバイオテロ対策として，位置づけられ，活用されるこ とが望まれる。

（日救急医会誌 $2006 ； 17: 712-20$ )

キーワード：救急車搬送，症候群サーベイランス，バイオテロ，発熱，流行探知アルゴリズム
\end{abstract}

\section{目 的}

2001年9月11日のアメリカにおける同時多発テロ， 炭疽菌事件以降，バイオテロによる脅威が現実化し ており，公衆衛生当局による準備が進められている。

An Experimental study for syndromic surveillance in ambulance transfer 1 国立感染症研究所感染症情報センター 2 東京消防庁救急部 3 順天堂大学医学部救急 · 災害医学 著者連絡先：干 162-8640 東京都新宿区戸山 1-23-1 原稿受理日：2005 年 12 月 9 日（05-065）
その際に最も重要となるのは，より早期にバイオテ 口の発生を感知するシステムの構築である。このた めにアメリカや台湾などでは既に様々な新しいサー ベイランスシステムが構築され，実際に運用され，ま た評価されている。それらはいずれも，診断された疾 患名に基づくサーベイランスではなく，症状·所見な どに関するサーベイランスであり，症候群サーベイ ランスと呼ばれている。その対象は多岐にわたり，一 般用医薬品, 救急外来, 救急車要請, 健康電話相談で 実際に運用されている ${ }^{1,2)}$ 。一般用医薬品や健康電話 相談での症候群サーベイランスは，医療機関への受 
診前でのサーベイランスであり，救急車要請や救急 外来での症候群サーベイランスは重症化例をより早 期に捉えられる。ニューヨーク市では救急外来にお いて既に 4 年間運用されており，その最初の 1 年の まとめが公表されている3)。この症候群サーベイラン スはファクシミリで毎日, 症状 (発熱, 呼吸器症状, 下痢, 嘔吐, 喘息, 到着時死亡)を呈する患者数を報 告するシステムで，ニューヨーク市の全ての救急外 来を持つ病院の約 $80 \%$ が参加している。この 1 年の 成績ではインフルエンザの流行よりはやく発熱の患 者数の増加を探知し，また認知されていなかったカ ンピロバクターの流行を探知している。

症候群サーベイランスは, 我が国においてはG8福 岡・宮崎サミット4), FIFA ワールドカップの際に行 われた5,6)。G8福岡・宮崎サミットは，感染症発生動 向調査での届け出疾患を出血性・皮虐病变症候群, 呼吸器症候群, 胃腸炎症候群, 神経系症候群, 非特 異的症候群に分類しなおして集計しており，対象患 者という意味では従来の感染症発生動向調査を越え るものではなかった。本格的な症候群サーベイラン スの最初となるFIFAワールドカップの症候群サーベ イランスでは，新規入院患者を皮膚・粘膜症状また は出血症状, 呼吸器症候群, 胃腸症候群, 神経系症 候群，非特異的感染症症候群に分類して把握するも のであった。入院時の把握のために正確性という点 では外来受診時より優れているが, 反面迅速性とい う点でも外来受診時より劣っていると考えられる。 また, FIFAワールドカップでは試合が行われた都市 でその期間およびその前後 2 週間（東京都は日本で の全試合日程の期間及びその前後 2 週間）のみに実 施されたために，そのベースラインをはじめとする 統計学的な性質を明らかにするまでは至らなかった。

本研究はこうしたこれまでの経験を踏まえ, 現在 諸外国で行われている症候群サーベイランスに相当 する症候群サーベイランスの開発を進めるために， 東京消防庁において過去10年間蓄積されている救急 車搬送の情報を用いて，その統計学的性質，および 実現可能性を検討する。

\section{材料と方法}

東京消防庁が保有する 1995 年 1 月 1 日から 2004 年12月31日までの救急車搬送のデータの内，救急隊 が記録する受傷形態が発熱であった救急車搬送を対 象とする。利用する情報は, 日付, 出動場所, 出動 場所と居住地の関係（同一行政区域内，東京都内同 一行政区域外, 東京都外, その他), 年令群, 地区 (丁 目番号まで）である。

統計学的検討は，行政区域内の救急車搬送数を都 全体の救急車搬送数で除した率を対象とする。その ベースラインは, その率を被説明変数とし, トレン ド，週数ダミー，曜日ダミー，休日明けダミーを説 明変数とする最小自乗法での予測值とする。また， 実際の搬送数の比率が, ベースラインよりも残差の 標準偏差の 3 倍以上上回った場合に, 異常な救急車 搬送数の増加が見られたと定義する。また，代替的 な基準として残差の標準偏差の 4，5倍も検討する。

ベースラインが 5 類定点報告疾患で代表される既 知の感染症流行の影響を受けていないことを確認す るために，前方視的に検討する2000年 1 月 1 日以降 2004 年 12 月 31 日までの期間で, 被説明変数は行政 区域単位での発熱による救急車搬送数とし，説明変 数は東京都全体での 5 類定点報告疾患の定点当たり 報告数として, 救急車搬送数をウエイトとする加重 最小自乗を用いて推定する。その際に 5 類定点報告

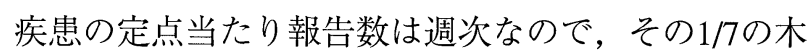
曜日の報告数とし，それらを連続する週で直線的に 結んだ值を日次のデータとして用いる。推定結果は 疾患の救急車搬送数に与える影響を比較するために 係数間の比較が可能なべー夕係数で示す。また，同 様の推定を，比率やベースラインに対しても行う。

異常な救急車搬送数の探知は, 前半の 5 年間をべー スライン推定のためだけに用い, 後半の 5 年間を前 方視的に解析する。つまり，2000年 1 月 1 日以降1995 年 1 月 1 日から前日までの情報を用いてベースライ ンの推定を行い，それに基づいて翌日の比率が基準 を上回った場合に，異常な救急車搬送数の増加が 


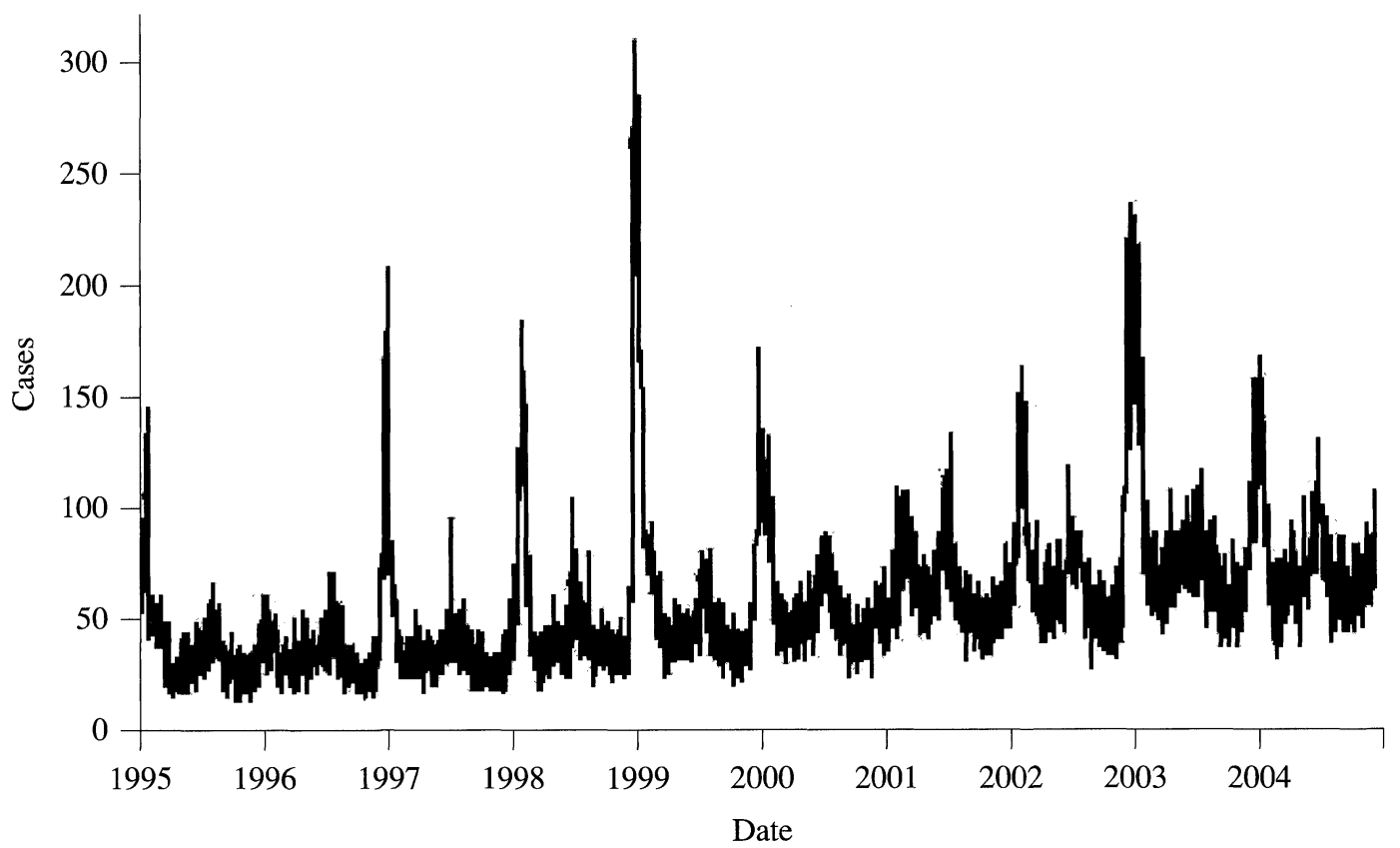

Fig. 1. Number of ambulance transferred in the whole of Tokyo.

あったと判断する。

システムの評価は，仮想的なシミュレーションと して行う。具体的には大きなショックの場合での人 為的な救急車搬送数の増加を $5,10,15$ 人とし, 小 さなショックの場合では救急車搬送数の増加を 1,2 , 3 人と想定する。前者を異常な救急車搬送数の増加 として探知するという意味での感度，後者を探知し ないという意味での特異度とする。

\section{結 果}

この 10 年間の発熱による東京都の救急車搬送数は 21,579件であった。1 日最大は312件，最小でも15件 であった。Fig.1に東京都全体での救急車搬送数を示 す。これによると冬期に大きな山があるのに加えて 夏期にも比較的大きな山があることが確認される。 例えば 2001 年夏期のピークは，2000年から 2001 年 にかけての冬期のピークを上回っている。

Fig. 2 は 23 区内のある区における比率と 3 種類の 基準における異常な救急車搬送数の増加が探知され た事例を示している。これによると通常は $3 \%$ 程度 であり顕著な季節性は確認できない。最も緩い基準
である 3 標準偏差では 17 回，4 標準偏差では 5 回， 5 標準偏差では 2 回の流行が探知されている。また, 流行が探知されたあとに救急車搬送数が持続的に高 い水準である傾向は確認されない。

Table 1には, 救急車搬送数, 比率, ベースライン を東京都全体での 5 類定点報告疾患の定点当たり報 告数に回帰させた結果がまとめられている。表の 1 , 2 列目から明らかなように救急車搬送数そのものは 多くの疾患の流行の影響を有意に受けている。ベー 夕係数は説明変数間での影響の大きさを比較可能で あるので，それによるとインフルエンザ，水痘，へ ルパンギーナ, 伝染性紅斑, 咽頭結膜熱の順で影響 が大きい。他方で比率では，第 3，4列が示している ように，比率そのものはなんらの疾患の有意な影響 も受けていない。そのベースライン $(5,6$ 列) もほ ほ同様である。

Table 2には，異常な救急車搬送数の増加が探知さ れた頻度が示されている。上段ではある行政区域に おける頻度，下段では行政区域を限定せずに東京都 全体での頻度を示している。つまり，上段は市区町 村の立場にとっての頻度，下段は東京都全体に対し 


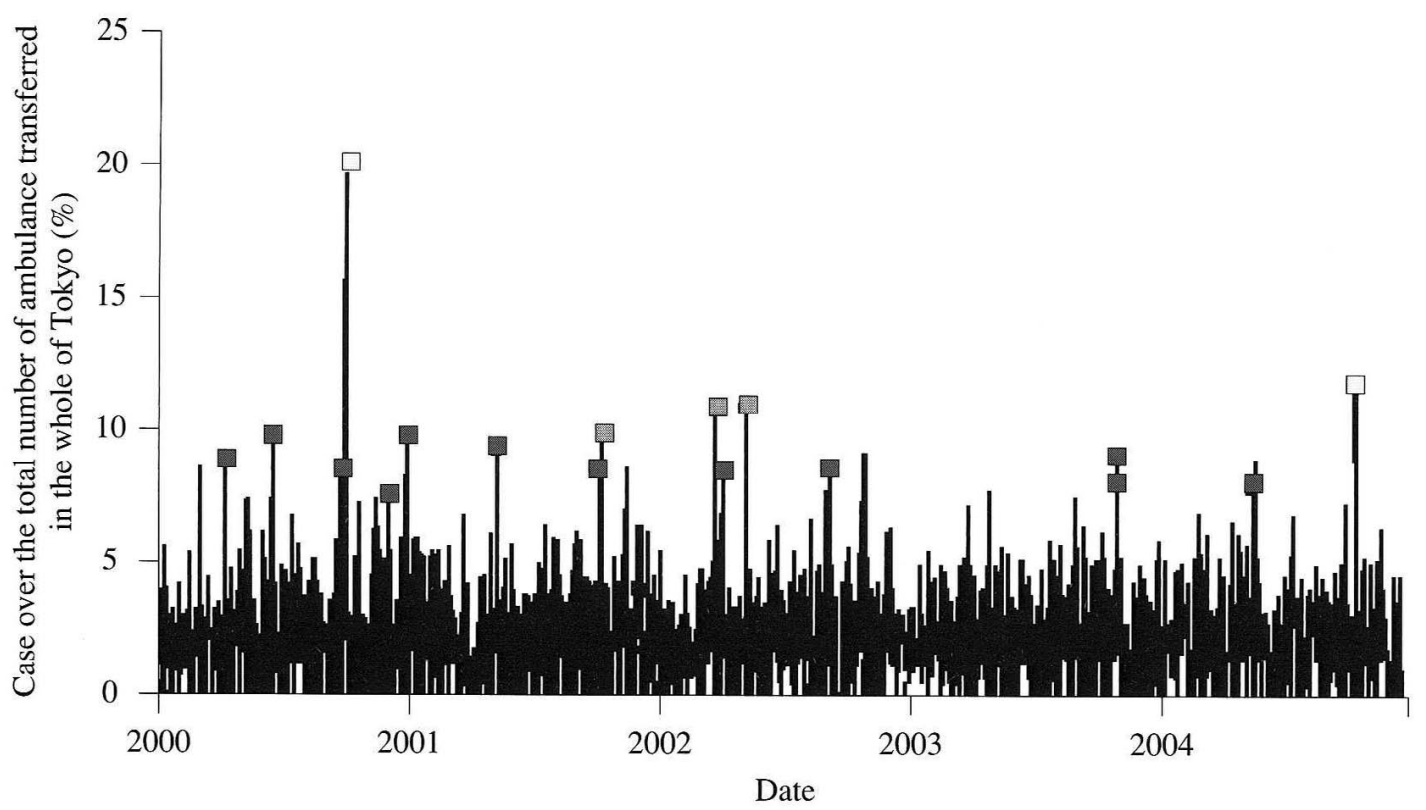

Fig. 2. Outbreak detection in a district.

Criterion of outbreak detection: $\square$ 3SD, $\square$ 4SD, $\square$ 5SD

Table 1. Relation among ambulance transferred and sentinel surveillance.

\begin{tabular}{|c|c|c|c|c|c|c|}
\hline \multirow[t]{2}{*}{ Disease } & \multicolumn{2}{|c|}{ Transferred } & \multicolumn{2}{|c|}{ Ratio } & \multicolumn{2}{|c|}{ Baseline } \\
\hline & $\beta$ coef. & $p$-value & $\beta$ coef. & $p$-value & $\beta$ coef. & $p$-value \\
\hline Influenza & .3937495 & 0.000 & -.0936752 & 0.914 & 1.573866 & 0.186 \\
\hline Pharyngoconjunctival fever & .0010471 & 0.000 & .002041 & 0.917 & .0475414 & 0.079 \\
\hline A hemolytic streptococcus adenoiditis & -.0034281 & 0.000 & .0028514 & 0.959 & -.105846 & 0.166 \\
\hline Infectious gastroenteritis & -.0325228 & 0.007 & .0449474 & 0.957 & 1.804282 & 0.117 \\
\hline Varicella & .0118833 & 0.000 & .0073424 & 0.952 & .2413332 & 0.147 \\
\hline Hand-foot and mouth disease & -.0027753 & 0.519 & .0067601 & 0.982 & .0936505 & 0.820 \\
\hline Erythema infectiosum & .0039809 & 0.000 & -.001453 & 0.979 & .1669267 & 0.062 \\
\hline Roseola infantum & -.0013636 & 0.000 & .0031842 & 0.883 & -.057255 & 0.054 \\
\hline Pertussis & .0000376 & 0.095 & -.0000664 & 0.966 & -.0018613 & 0.380 \\
\hline Rubella & -.0004876 & 0.000 & .0001399 & 0.975 & -.0110323 & 0.078 \\
\hline Herpangina & .0846061 & 0.000 & -.0323269 & 0.960 & .7318651 & 0.413 \\
\hline Measles in child & -.000217 & 0.364 & .0001541 & 0.993 & -.0272234 & 0.234 \\
\hline Mumps & -.0011601 & 0.183 & -.0042224 & 0.944 & -.2133885 & 0.110 \\
\hline Acute hemorrhagic conjunctivitis & -.0002831 & 0.070 & .0006 .543 & 0.952 & -.0046329 & 0.756 \\
\hline Epidemic Keratoconjunctivitis & -.0068471 & 0.000 & -.0112969 & 0.928 & .0612881 & 0.721 \\
\hline Constant & .4209506 & 0.000 & 29.78892 & 0.000 & 52.97169 & 0.000 \\
\hline No. of samples & \multicolumn{2}{|c|}{50752} & \multicolumn{2}{|c|}{50752} & \multicolumn{2}{|c|}{50752} \\
\hline Adjusted $R^{2}$ & \multicolumn{2}{|c|}{0.0359} & \multicolumn{2}{|c|}{-0.0003} & \multicolumn{2}{|c|}{0.0006} \\
\hline
\end{tabular}

Note: The dependent variables are ambulance transferred (the first and second columns), ratio of number of transferred in a district over the number in the whole of Tokyo (the third and fourth columns), and estimated baseline in the prospective analysis (the fifth and sixth columns). Explanatory variables are the reported number of sentinel surveillance in the whole of Tokyo, which are converted to the daily data form weekly. Sample period is from January 1st, 2000 to 31st December, 2004. Estimation method is the weighted least square weighted by the number of ambulance transferred in a district. " $\beta$ coef." Indicates how the dependent variables change when each explanatory variable increases by one standard deviation. If is is one, the dependent variables increases by one standard deviation of the dependent variables due to increasing in an explanatory variable by one standard deviation. "Adjusted $R^{2}$ " indicates how proportion of the depended variables are explained by all explanatory variables in total. If it is one, all change in the dependent variable are explained by the model. 
Table 2. Frequency of outbreak detection (\%).

\begin{tabular}{lccc}
\hline & \multicolumn{3}{c}{ Alert Detection Criterion } \\
& 3 SD & 4 SD & 5 SD \\
\hline In a district & & & \\
All area & 1.10 & 0.30 & 0.09 \\
The special 23 wards & 0.54 & 0.11 & 0.03 \\
Other area & 1.57 & 0.46 & 0.15 \\
\hline In total & & & \\
The whole of Tokyo & 39.68 & 13.05 & 4.42 \\
The whole of special 23 wards & 11.82 & 2.46 & 0.60 \\
The whole of other area & 32.48 & 11.01 & 3.87 \\
\hline
\end{tabular}

Note: This tables show the frequency of outbreak detection in a district or in the whole of Tokyo under three criterion of outbreak detection. $1 \%$ in this table means that outbreak are detected in every 100 days. "SD" indicates standard deviation as criterion for outbreak detection. The upper panel show the frequency of outbreak detection in a district and the lower panel shows the frequency of outbreak detection in total of the whole of Tokyo, special 23 eards, or other areas.

Table 3. Sensitivity and specificity (\%).

\begin{tabular}{lcccc}
\hline & Additional transferred & 3 SD & 4 SD & 5 SD \\
\hline All area & & & & \\
Specificity & 1 & 89.62 & 94.58 & 97.07 \\
& 2 & 70.91 & 84.00 & 79.58 \\
\hline Sensitivity & 3 & 51.20 & 67.95 & 45.33 \\
& 5 & 73.53 & 58.62 & 81.90 \\
& 10 & 95.96 & 90.18 & 99.23 \\
\hline The special 23 wards & 15 & 99.23 & 97.68 & 99.91 \\
Specificity & & & & 99.33 \\
& 1 & 98.05 & 99.59 & 96.87 \\
\hline Sensitivity & 2 & 91.07 & 97.54 & 17.12 \\
& 3 & 77.76 & 91.06 & 66.30 \\
& 5 & 52.70 & 31.46 & 98.43 \\
\hline Other area & 10 & 92.05 & 81.11 & 99.69 \\
Specificity & 15 & 98.43 & 95.36 & 92.17 \\
& 10 & & & 64.90 \\
\hline
\end{tabular}

Note: Sensitivity is defined by the proportion of outbreak detection to artificial additional transferred by 5,10 or 15 cases when outbreak was not detected in actual data. Specificity is defined by the proportion that outbreak was not detected to artificial additional transferred by 1,2 or 3 cases when outbreak was not detected in actual data. 
て責任を負う部局にとっての頻度である。ある行政 区域においては 3 標準偏差を基準とすると平均的に は $1.1 \%, 23$ 区内では $0.5 \%$, 多摩地区では $1.6 \%$ と, 年に数回の程度異常な救急車搬送数の増加が探知さ れた。また，基準をより厳しくすると，それに応じ て頻度は減少し $0.1 \%$ 前後まで低下する。他方で東京 都全体では単純には上段の49倍とはならないが，3 標準偏差を基準とすると平均的には $39.7 \%$ ，つまり 2.5 日に一回異常な救急車搬送数の増加が探知され た。基準をより高くしても同様で，5標準偏差では平 均的には $4.4 \%$ まで低下し，ほほ 1 カ月に一回異常な 救急車搬送数の増加が探知された。

Table 3は， 3 種類の基準で感度・特異度がまとめら れている。特異度は都全体, あるいは 23 区では非常 に高く, 追加的な救急車搬送数が 1 名であれば $90 \%$, 3 名であっても50\%を越えている。つまり 2 回に一回 は誤って流行を探知する。しかしながら多摩地区では 特異度が低下し，28.4\%とほほ 4 回に 3 回は誤って流 行を探知する。当然の事ながら基準をあげると特異度 は増加し，5標準偏差では多摩地区でも50\%を越える。

他方で感度は高い。都全体ではバイオテロの規模 が 5 人であっても73\%の確率で探知できる。23区で その感度は $52.7 \%$ まで低下するが，10人であれば感 度は90\%を越える。基準をあげると感度は低下する。 23区内であれば，5標準偏差では，5人の救急車搬送 数の増加に対しては $17.1 \%$ まで低下し， 7 回に一回程 度しか探知されない。10人になると $66.3 \%$ なのでや はり 3 回に一回は探知されない。バイオテロの規模 が 15 人となると $98.4 \%$ とほぼ確実に探知される。

\section{考察}

日本における最初の本格的な症候群サーベイラン スであるFIFAワールドカップの際に行われた症候群 サーベイランスは，入院時の症状に関して行われて おり，そのために迅速性はやや乏しい。他方，本研 究は, 現在アメリカや台湾で既に実用化されている, 過去のパターンから逸脱した流行をより早期に探知 するための症候群サーベイランスを目指している。
また，G8福岡・宮崎サミットあるいはFIFAワール ドカップの際の症候群サーベイランスは，事前に異 常な患者数の増加を探知するアルゴリズムを設定し ておらず，事後的に検討したにすぎない。その意味で これらは自動的な異常な患者数の増加を探知するこ とよりもむしろデー夕収集に主眼がおかれていたと 思われる。それに比して本研究では，前方視的に探知 アルゴリズムを設定し運用した際の，異常な救急車 搬送数の増加の探知, またその統計学的性質を検討 している。実際の症候群サーベイランスは，日々デー 夕が更新され，それを評価する前方視的な環境であ るために，本研究ではそうした実際の運用環境にお いて探知アルゴリズムの性質を評価している。

したがって，本研究は，現在国際的に主流となっ ている過去のパターンから逸脱した流行の早期探知 を目的とする症候群サーベイランスとして，救急車 搬送数による症候群サーベイランスを日本で初めて 試みたものであり，また，その探知アルゴリズムを 実際の状況に即した環境で統計学的に検討した研究 であると位置づけられる。

Fig. 2 で示された 23 区内のある区における比率の 変動を典型的な例とすると, 通常は低い水準で顕著 な季節性もなく安定的に推移している。また，流行 が探知された日における救急車搬送数の増加は突発 的であり，持続しない。これらのことから，こうし た比率で見ることによって，Fig.1で示されるような 顕著な季節性は除去され, 救急車搬送数の増加のみ を捉えることに成功したと判断される。これは，顕 著な季節性によって示される既知の感染症の流行パ ターンが除去され，その影響を受けずに，真に知り たい異常な救急車搬送数の増加を捉えている。一般 に流行探知は救急車搬送数あるいは患者数等そのも のを観察して検討される場合が多いが，その場合に は既知の感染症に基づく季節パターンの除去が必要 であり，それをべースラインの推定によって行われ る。つまりベースラインの推定の精度が，バイオテ 口あるいは異常な感染症の増加の探知にとって重要 になるが，しばしば十分な過去のデータの蓄積がな 
されておらず，その場合には季節パターンの推定も 精度が低くならざるを得ない。Table 2の第 2 列にお いて，比率を有意に説明する 5 類定点報告疾患がな いことからも，本稿のように比率を分析対象にする ことによって季節パターンが完全とは言えなくとも その大部分が除去されていることが伺える。その意 味で，比率を分析の対象とすることは，季節パター ンの除去という意味で適切であると結論づけられる。 さらに，本稿ではそうした比率に対してさらにべー スラインを推定し, 残されているかも知れない季節 パターンも除去しているので, 二重の意味で季節性 が除去されている。Table 1からそれが統計学的にも 確認される。

また，例えばインフルエンザは通常 1 月下旬から 2 月上旬にかけて流行のピークを迎えることが多い が，2004/2005 シーズンでは 2 月末から 3 月にかけ て流行のピークを迎えたが，このように東京都全体 で通常の流行期とはずれて流行した場合においても， 比率を用いる方が頑健である。この場合, 通常の流 行期からずれた流行は, 過去の季節パターンから逸 脱しているので, 救急車搬送数あるいは患者数等そ のものを観察して検討される場合には，流行として 探知される。逆に，本稿のように比率を観察する場 合には, 地域的な救急車搬送数あるいは患者数と, 東京都全体での増加は同じ割合で増加するので, 異 常な救急車搬送数の増加とは判断されない。バイオ テロの犠牲者が東京都全体で均質的に発生するとは 考えにくく，その意味でもバイオテロあるいは既知 の感染症であっても異常な地域的な流行の探知の探 知には比率を用いる方が優れていると言えよう。

ここでは試行的に 3 種類の異常な救急車搬送数の 増加を判断する基準を試みたが，バイオテロ対策に おいては特異度よりも感度の方が相対的に重視され ることを考えると 3 標準偏差が妥当であると思われ る。この場合, バイオテロを含めて異常な患者数の 増加の規模が10名程度であれば90\%以上の確率で探 知可能である事が明らかにされた。この対象がある 行政区域に限定されることを考えると，10名の救急
車搬送数の増加をほぼ確実に探知できることは，こ のシステムが求められている能力を有していると判 断されよう。その裏返しで特異度はやや劣る。そも そも症候群サーベイランスは，症状をモニターする もので正確性には劣る。したがって，その正確性を 増し，また感度を落とさず特異度を挙げるためには 他の側面をモニターしている症候群サーベイランス との比較が必要不可欠である7)。日本においてはこ のような比較が可能な症候群サーベイランスとして は, 一般用医薬品と外来受診の情報を用いた症候群 サーベイランスが試験的に行われている ${ }^{8,9)}$ 。こうし た研究とも共同して, より正確で信頼性の高い症候 群サーベイランスの構築が必要である。本研究での 救急車搬送数を用いた症候群サーベイランスは，そ うした多面的な症候群サーベイランスの重要な一部 として位置づけられる。

一般用医薬品と外来受診といった症候群サーベイ ランスの他の情報源と比較して, 救急車搬送数にお ける症候群サーベイランスとしての利点は多い。第 一に一般用医薬品や医療機関を通じた情報収集では, 一部の協力薬局あるいは協力医療機関に限定され, その意味で網が小さくまた粗くならざるを得ないが, 救急車搬送数では管轄地域全域での情報を収集でき るために，網が広くその目が細かい。そうした救急 車搬送の情報が持つ広域性は大きな利点である。第 二に，東京都においては既に日々の業務として情報 が電子化されて蓄積されており，医療機関での情報 収集と比べて, 改めて情報収集のためのシステムを 開発する必要がない。そのため既存のシステムに追 加的に症候群サーベイランスを運用することが可能 で，非常に安価に症候群サーベイランスを実施する ことができる。第三に, 東京都に関しては過去10年 間の情報を蓄積しており，安定したベースラインを 得ることが可能で，長期間の評価が可能である。

他方で，救急車搬送数であることの制約も少なく ない。救急車搬送では出動先住所は記録されるが, それは必ずしも居住地ではないので, 地域的な流行 の探知という意味では, 医療機関からの情報収集よ 
りも劣る可能性がある。また，救急車搬送の情報は 行政上収集された情報であるので，一般用医薬品よ りも個人情報保護への配慮をしなければならず，倫 理的な配慮が必要となる。そもそも東京都の場合に は症状の情報が電子化されており，それを有効に利 用することが可能であるが，この症状は国が報告を 求めている事項に含まれていないために，必ずしも 東京都以外の全ての消防機関において実施されてい るわけではない。むしろ, 症状の情報を収集し, そ れを電子化している消防機関は少数であると思われ る。症状の情報が収集されていなければ，本稿で検 討した様な形での症候群サーベイランスを直ちに実 施することはできず，実施するためには消防機関の システムの変更を伴う一定の投資を必要とする。そ れらの場合でも, 救急車搬送数の情報は症候群サー ベイランスの情報源として有力であることには変わ らないので，それを普及させるためには，国が症状 の報告を求めることが重要になると思われる。

サーベイランスシステムの評価は，本来であれば 何らかの意味で確認された事象をゴールドスタン ダードとし, それに対する感度, 特異度を指標とし て行われる。しかしながら症候群サーベイランスの 場合は，過去のパターンから逸脱した流行（バイオ テロを含む）を検出することを目的とするので，確 認された過去のパターンから逸脱した流行の時期や 規模の情報が必要となる。しかしながら，それを明 確に定義することは難しいし，また幸いなことに， 既知のバイオテロの経験はない。そこで仮想的なシ ミュレーションとして評価することが，これまでの 研究では行われており，本研究もそれに従った ${ }^{9-14)}$ つまり，デー夕上の救急車搬送数を人為的に大きく 増やすことで, 大きなショックを実際の救急車搬送 数のデー夕に加えることによって，過去のパターン から逸脱した流行を起こし，それがシステムによっ て異常な救急車搬送数の増加として感知されたかど うかでその感度を確認する。また, 逆に日常的な救 急車搬送数の変動範囲内の小さなショックを, 過去 のパターンから逸脱した異常な救急車搬送数の増加
として検出してはいけないので，そうした誤った探 知をするかどうかでその特異度を求める。したがっ て，本稿における評価方法は，標準的であり妥当で あると言える。

\section{結論}

本稿は救急車搬送数の情報を用いた症候群サーベ イランスがバイオテロを含む異常な救急車搬送数の 増加を検知する十分な感度を有しており，実用化を 検討するに十分に值すると思われる。一方で特異度 を高める努力も必要であり，その改善はシステムの 有効性を高めるであろう。また，既に東京消防庁内 では電子的に記録されるシステムが確立しており， それを本稿のような形で解析評価すれば，世界最大 の人口を対象とする症候群サーベイランスとなる。 その実用性も極めて高いので，早期に東京都などに おけるバイオテロ対策として，位置づけられ，利用 されることが望まれる。

謝辞 デー夕を御提供いただきました東京消防庁救急 部に深謝致します。本研究は平成16年度厚生労働科学研 究費補助金新興・再興感染症研究事業「SARS，バイオテ ロ，インフルエンザ対策としてのリアルタイム・アウト ブレーク・サーベイランスシステム構築のための基礎的 研究 (H16- 新興 -14)」(代表 : 大日康史国立感染症研究 所感染症情報センター主任研究官) の研究成果の一部で ある。

\section{文献}

1) Henning KJ: What is syndromic surveillance? MMWR Morb Mortal Wkly Rep 2004; 53(Suppl): 5-11.

2) Siegist DW, Tennyson SL: Technologically-based biodefense. Potomac institute fro policy studies, 2003.

3) Buehler JW, Berkelman RL, Hartley DM, et al: Syndromic surveillance and bioterrorism-related epidemics. Emerg Infect Dis 2003; 9: 1197-204.

4）松井珠乃, 高橋央, 大山卓昭, 他:G8福岡·宮崎サミッ ト 2000 に伴う症候群サーベイランスの評価. 感染症誌 2002; 76: 161-6.

5）鈴木里和, 大山卓昭, 谷口清洲, 他 : 2002 年FIFA ワー ルドカップ開催に伴う感染症 ·症候群別サーベイラン ス. 病原微生物情報 $2003 ; 24: 37-8$. 
6）谷口清州, 木村幹男, 鈴木里和, 他: 症候群サーベイラ ンスの実施とその評価に関する研究. 平成 14 年度厚生 労働科学研究費補助金新興·再興感染症研究事業「大規 模感染症発生時における行政機関，医療機関等の間の広 域連携に関する研究」総括. 分担研究報告書, 2003.

7) Lawson B: lend me your EARS: a step-by-step approach to implementing the early aberration reporting system in a metropolitan public health department. presented at Bio-Detection Surveillance. Early Aberration Reporting System (EARS) Workshop, 2005.

8) Ohkusa Y, Shigematsu M, Taniguchi K, et al: Experimental surveillance using data on sales of over-the-counter madications--Japan, November 2003-April 2004. MMWR Morb Mortal Wkly Rep 2005; 54(Suppl): 47-52.

9）大日康史，杉浦弘明，菅原民枝，他：症状における症候 群サーベイランスのための基礎的研究. 感染症誌 2006; 80: 366-76.
10) Hutwagner L, Browne T, Seeman GM, et al: Comparing aberration detection methods with simulated data. Emerg Infect Dis 2005; 11: 314-6.

11) Mandl KD, Reis B, Cassa C: Measuring outbreak-detection performance by using controlled feature set simulation. MMWR Morb Mortal Wkly Rep 2004; 53(Suppl): 130-6.

12) Nordin JD, Goodman MJ, Kulldorff M, et al: Simulated anthrax attacks and syndromic surveillance. Emerg Infect Dis 2005; 11: 1394-8.

13) Buckeridge DL, Burkom H, Moore A, et al: Evaluation of syndromic surveillance systems --design of an epidemic simulation model. MMWR Morb Mortal Wkly Rep 2004; 53 (Suppl): 137-43.

14) Kulldorff M, Zhang Z, Hartman J, et al: Benchmark data and power calculations for evaluating disease outbreak detection methods. MMWR Morb Mortal Wkly Rep 2004; 53(Suppl): 144-51.

\section{ABSTRACT \\ An Experimental Study for Syndromic Surveillance in Ambulance Transfer \\ Yasushi Ohkusa $^{1}$, Yukihiko Kawaguchi ${ }^{2}$, Tamie Sugawara ${ }^{1}$, Tetsu Okumura ${ }^{3}$ Kiyosu Taniguchi ${ }^{1}$, and Nobuhiko Okabe ${ }^{1}$ \\ ${ }^{1}$ Infectious Diseases Surveillance Center, National Institute of Infectious Diseases \\ ${ }^{2}$ Emergency Medical Service Division, Tokyo Fire Department \\ ${ }^{3}$ Department of Acute and Disaster Medicine, Juntendo University School of Medicine}

Objective: To study ambulance transfers in Tokyo as a potential source of Syndromic Surveillance, and examine the possibility of practical application from a statistical view point. Method and Material: The Tokyo Fire Department has recorded the chief complaints of ambulance transferred patients for more than 10 years. We use the number of patients transferred by ambulance due to fever from January 1st, 1995 to December 31st, 2004. We perform the calculations prospectively for days after January 1st, 2000. Meaning, we estimate the baseline from January 1st, 1995 to the day before any given day. Then we predict the number of ambulance transfers in that day. An outbreak is detected if the actual number is larger than the estimated by three times the standard deviation of residuals. So as to check sensitivity and specificity, we add artificial transfers to the data and judge whether they are detected or not. Results: In an average city, we found outbreaks at $1.1 \%$, i.e. a few times a year. However, it rises to $39.7 \%$, i.e. once every two and a half days, in the whole of Tokyo. Specificity in the whole of Tokyo or other urban areas is high and an outbreak is not detected in the case of only one additional patient being transferred. Sensitivity is also high because an outbreak can be detected even if there are only 5 victims of a bioterrorist attack. Discussion: We can evaluate that this system has a high ability to detect outbreaks. However, so as to raise precision and specificity without losing sensitivity, we should use other syndromic surveillance monitoring or monitor other aspects besides ambulance transfers at the same time. The information on ambulance transfers is already electronically recorded. Therefore, if we can add an analytical tool such as the one described in this paper to the system, we can operate a system of syndromic surveillance which covers the largest population in the world. Since its usefulness is confirmed in this paper, we hope the local government of Tokyo will adopt and operate this system as a counter measure for bioterrorism attacks.

(JJAAM $2006 ; 17: 712-20)$

Keywords: ambulance transfer, syndromic surveillance, bioterorism attack, fever, outbreak detection algorithm

Accepted for publication on December 9, $2005 \quad$ (05-065) 